\title{
IMPLEMENTATION OF INTERACTIVE MULTIMEDIA LEARNING BASED ON COGNITIVE LOAD THEORY IN GRADE 5 STUDENTS OF ELEMENTARY SCHOOL
}

\author{
Rissa Prima Kurniawati, Fida Rahmantika Hadi, Vivi Rulviana \\ Universitas PGRI Madiun \\ rissaprimakurniawati14@gmail.com
}

\section{Article History}

accepted 09/07/2018

approved 01/08/2018

published 17/09/2018

\section{Keywords}

Interactive Multimedia

Learning, Cognitive Load

Theory

\begin{abstract}
Mathematics learning in elementary schools is usually only one-way, teacher-centered, teachers only explain the material, and using existing media in the school,, students just listen and perform tasks given by the teacher. This resulted in students' understanding of math lessons and their learning achievement decreases. Therefore needed a good media that is interactive multimedia learning based on Cognitive Load Theory (CLT). This study aims to describe the application of interactive multimedia learning based on Cognitive Load Theory (CLT) on students of grade 5 SDN 3 Klegen. This research is a qualitative research. The subjects in this study are students of grade 5 SDN 3 Klegen Madiun City. Based on the results of research, on learning by using interactive learning multimedia based cognitive load theory (CLT) is divided into three activities, namely the initial activities, core activities, and closing activities. The average result of the questionnaire score was $88.27 \%$, so the questionnaire was considered good. And also the average value of class 5 SDN 3 Klegen of 78,5 from total 26 students. Students who get grades under the KKM that is 70 as many as 4 students from 26 students. It shows that $84.61 \%$, so it can be concluded that the most students already understand the material of cube and beam volume.
\end{abstract}

Social, Humanities, and Education Studies (SHEs): Conference Series https://jurnal.uns.ac.id/shes

p-ISSN 2620-9284 e-ISSN 2620-9292 


\section{PENDAHULUAN}

Perkembangan ilmu teknologi semakin hari semakin bertambah pesat. Hal tersebut akan berdampak pada perubahan dan pola pikir dalam kehidupan masyarakat. Oleh karena itu untuk mewujudkan masyarakat yang berkualitas baik, maka kemajuan teknologi harus diimbangi dengan kemajuan dibidang pendidikan, salah satunya yaitu pendidikan matematika.

Di Sekolah Dasar, pembelajaran matematika yang dilakukan di kelas, hanya berpusat pada guru. Guru biasanya hanya menjelaskan materi dengan metode ceramah dan menulis dipapan tulis tanpa menggunakan media pembelajaran. Kemudian guru memberikan contoh soal, dilanjutkan memberikan soal. Dan siswa disini mendengarkan penjelasan dari guru, kemudian mengerjakan soal yang diberikan oleh guru. Pembelajaran matematika yang berpusat pada guru, mengakibatkan siswa menjadi cepat bosan dan juga membuat siswa masih menganggap bahwa matematika itu pelajaran yang sulit serta tidak menyenangkan. Oleh karena itu, diperlukan suatu media pembelajaran yang menarik yaitu multimedia pembelajaran interaktif.

Multimedia adalah media yang menggabungkan dua atau lebih media yang terdiri dari gambar, teks, grafis, foto, audio, animasi, dan video. Multimedia memberikan kesempatan bagi siswa untuk belajar tidak hanya belajar dari sumber belajar seperti guru, tetapi memberikan banyak kesempatan kepada siswa untuk mengembangkan kognitifnya dengan lebih baikdan inovatif. Aspek-aspek multimedia pembelajaran interaktif dianggap akan meningkatkan pembelajaran sehingga dapat meningkatkan pemahaman siswa dan juga hasil belajar siswa.Pemahaman suatu materi sangatlah penting untuk membantu menyelesaikan masalah atau soal matematika.

Matematika merupakan salah satu pelajaran yang dianggap banyak siswa adalah pelajaran yang sulit. Hal ini dikarenakan, matematika merupakan ilmu abstrak dan juga pada matematika biasanya terdiri dari simbol, angka, dan formula (rumusrumus)matematika. Penyajian materi matematika yang kurang baik akan menambah beban kognitif pada memori kerja siswa. Proses pembelajaran dikatakan yang efektif terletak pada optimalisasi beban kognitif dalam kapasitas memori kerja yang terbatas (Kuan, 2010:7). Oleh karena itu, dalam mendesain multimedia pembelajaran interaktif perlu mempertimbangkan beban kognitif tersebut. Sweller mengungkapkan, Cognitive load theory (CLT) merupakan suatu teori pengajaran yang berdasar pada pengetahuan dari arsitektur kognitif yang dimiliki oleh manusia (Plass dkk, 2010:29).

Menurut R.C. Clark dkk, terdapat tiga Cognitive load dalam memori kerja, yaitu 1) intrinsic cognitive load (beban kognitif intrinsic), 2) germanycognitive load (beban kognitif germany), dan 3) extraneouscognitive load (beban kognitif extraneous) (Kuan, 2010: 6). Suatu pembelajaran yang efektif dapat dicapai dengan mengelola Cognitive load intrinsic, mengurangi Cognitive load extraneous, dan meningkatkan Cognitive load germany (Kuan, 2010:7). Penyampaian materi yang sulit dengan cara yang mudah, baik, dan menarik, dapat mengurangiextraneouscognitive loaddalam suatu pembelajaran dan mengelola intrinsic cognitive load sehingga materi dengan mudah dapat dipahami oleh siswa. Oleh karena itu, diperlukan multimedia pembelajaran interaktif berbasis Cognitive Load Theory (CLT) agar materi dapat dipahami oleh siswa. Jika pemahaman siswa meningkat akan mengakibatkan hasil belajar siswa meningkat.Tujuan penelitian dalam penelitian ini adalah mendeskripsikan penerapan 
multimedia pembelajaran interaktif berbasis Cognitive Load Theory (CLT) pada siswa kelas 5 SDN 3 Klegen.

\section{METODE PENELITIAN}

Penelitian ini merupakan penelitian kualitatif. Menurut Ghony dan Almanshur (2016:2), penelitian kualitatif merupakan upaya untuk mendeskripsikan dan menganalisis fenomena, aktivitas sosial, peristiwa, persepsi, kepercayaan, sikap, dan perilaku individu atau kelompok orang dengan melibatkan beberapa metode-metode yang ada. Pada penelitian ini penulis menggunakan pendekatan kualitatif yang disajikan secara deskriptif, dimana penelitian ini mengarah pada pendeskripsian secara rinci dan mendalam mengenai kondisi tentang apa yang sebenarnya terjadi menurut apa adanya di lapangan studinya. Suryabrata (2011:76) menjelaskan bahwa pendekatan deskriptif bertujuan untuk membuat pencandraan (deskripsi) mengenai situasi-situasi atau kejadian-kejadian secara sistematis, faktual, dan akurat.

Subyek dalam penelitian ini adalah siswa kelas 5 SDN 3 Klegen Kota Madiun sebanyak delapan belas siswa. Teknik pengumpulan data pada penelitian ini adalah angket, wawancara, dokumentasi, dan tes. Data yang telah terkumpul dianalisis dengan menggunakan teknik analisis kualitatif, salah satu modelnya adalah teknik analisis interaktif yang dikembangkan oleh Miles dan Huberman (dalam Putra, 2011:73) yang meliputi kegiatan sebagai berikut: 1) Mereduksi data. Mereduksi data merupakan suatu proses menyeleksi, memfokuskan, dan menyederhanakan semua data mentah dan kasar yang telah diperoleh. 2) Menyajikan data. Menyajikan data merupakan kegiatan menyajikan hasil reduksi data secara naratif, sehingga memungkinkan penarikan kesimpulan dan keputusan pengambilan tindakan. 3) Menarik kesimpulan serta verifikasi. Menarik kesimpulan serta verifikasi merupakan suatu proses memberikan kesimpulan terhadap hasil penafsiran dan evaluasi yang meliputi pencarian makna data dan pemberian penjelasan.Dalam penelitian ini, data yang dianalisis adalah sebagai berikut:

1. Analisis data angket siswa

Untuk menganalisis hasil angket siswa digunakan rumus menurut Menurut

Akbar (2010: 213) yaitu sebagai berikut.

$V=\frac{T S E V}{S_{\max }} \times 100 \%$

Keterangan:

$V \quad=$ Validitas/hasil angket

$T S E V=$ Total Skor Empirik

$S_{\max }=$ Skor maksimal yang diharapkan

Kesimpulan analisis data disesuaikan dengan kriteria hasil angket sebagai berikut:

Tabel 1 Kriteria hasil angket

\begin{tabular}{|c|c|c|}
\hline No. & Interval & Kategori Hasil Angket \\
\hline 1. & $80 \%-100 \%$ & Baik \\
\hline 2. & $60 \%-79 \%$ & Cukup Baik \\
\hline 3. & $50 \%-59 \%$ & Kurang Baik \\
\hline 4. & $<50 \%$ & Tidak Baik \\
\hline
\end{tabular}




\section{HASIL DAN PEMBAHASAN}

Penelitian ini bertujuan untuk mendeskripsikan penerapan multimedia pembelajaran interaktif berbasis Cognitive Load Theory (CLT) pada siswa kelas V SDN 3 Klegen Kota Madiun. Berikut adalah pembahasan dari penelitian ini:

\section{A. Penerapan Multimedia Pembelajaran Interaktif Berbasis Cognitive Load Theory (CLT) Pada Siswa Kelas V SDN 3 Klegen}

Multimedia Pembelajaran Interaktif Berbasis Cognitive Load Theory (CLT) satu kali pertemuan. Setiap pertemuan terbagi dalam tiga kegiatan yaitu kegiatan awal, kegiatan inti, dan kegiatan penutup. Kegiatan awal dimulai dengan memberikan salam kepada siswa, memberikan motivasi pentingnya matematika dalam kehidupan sehari-hari. Langkah ini bertujuan untuk meningkatkan motivasi siswa untuk belajar matematika sehingga prestasi belajar matematika akan meningkat. Hal ini didukung pendapat Orton (1992:9-10) bahwa siswa yang termotivasi, tertarik, dan mempunyai keinginan untuk belajar lebih banyak.

Langkah selanjutnya, peneliti menyampaikan tujuan pembelajaran.Penyampaian tujuan pembelajaran dalam penelitian ini bertujuan untuk memusatkan perhatian siswa pada topik yang akan dibahas. Dengan pemberiantujuan pembelajaran, siswa mengetahui arah yang ingin dicapai dalam pembelajaran, sehingga siswa termotivasi untuk melaksanakan pembelajaran dan akhirnya hasil pembelajaran dapat tercapai secara maksimal. Pemberian motivasi kepada siswa bertujuan untuk menciptakan suatu kondisi atau proses yang mengarahkan siswa untuk melakukan aktifitas belajar, sehingga akan menimbulkan rasa semangat untuk belajar pada diri siswa. Hal ini sesuai dengan pendapat Sardiman (2007:75) yang menjelaskan bahwa motivasi adalah hal yang tidak dapat dipisahkan dalam pembelajaran karena merupakan faktor psikis yang bersifat non-intelektual dan berperan untuk menumbuhkan perasaan senang dan juga menambah semangat dalam belajar.

Setelah guru menyampaikan tujuan pembelajaran, guru juga mengingatkan kembali tentang materi prasyarat yang diperlukan untuk mempelajari materi volume kubus dan balok. Dalam hal ini seorang guru memberikan beberapa pertanyaan kepada siswa yaitu tentang sifat-sifat kubus dan balok misalnya berapakah jumlah sisi dan rusuk pada kubus. Hal ini didukung pendapat (Crawford, 2001:5) bahwa pengetahuan yang dimiliki dapat berfungsi sebagai landasan yang dapat dijadikan dasar untuk membangun pengetahuan baru. Dengan mengingatkan kembali materi yang dimiliki siswa yaitu materi sifat-sifat kubus dan balok, akan membangun motivasi siswa untuk belajar. Siswa yang termotivasi akan lebih siap untuk menerima pelajaran dan akan mencapai hasil belajar yang lebih baik. Selain itu, dengan mengingatkan kembali materi prasyarat akan memudahkan siswa untuk memahami suatu materi. Sehingga dengan mengingatkan kembali materi prasyarat ini, dapat mengelola intrinsic cognitive load.

Pada kegiatan inti dimulai dengan menjelaskan materi dengan menggunakan multimedia pembelajaran interaktif. Multimedia pembelajaran interaktif ini dibuat dengan menggunakan software macromedia flash. Dengan 
menggunakan multimedia pembelajaran interaktifini, materi yang sulit dapat ditampilkan dengan lebih mudah, menarik, sehingga dapat dipahami oleh siswa, dalam hal ini terjadi pengelolaan intrinsic cognitive load. Selain itu, multimedia pembelajaran interaktif ini juga dapat menampilkan gambar dan animasi yang lebih menarik, dapat bergerak, dan lebih kontekstual. Sehingga dapat membuat siswa termotivasi dan terfokus untuk memperhatikan penjelasan dari guru, dalam hal ini terjadi pengurangan extraneous cognitive load.Akan tetapi pemberian gambar atau animasi yang banyak dapat menambah extraneous cognitive load.

Kegiatan selanjutnya yaitu guru memberikan contoh soal. Dengan pemberian contoh soal dapat mengelola intrinsic cognitive load dan meningkatkan germany cognitive load. Sehingga dapat memudahkan siswa dalam memahami suatu materi dan dengan pemberian contoh soal kepada siswa, akan berakibat terjadi suatu interaksi berfikir pada diri siswa, sehingga siswa dapat menyelesaikan suatu soal secara mandiri.

Kegiatan selanjutnya yaitu guru memberikan soal evaluasi untuk dikerjakan oleh semua siswa. Kemudian guru meminta semua siswa untuk memecahkan masalah yang ada pada soal. Soal yang diberikan adalah soal pilihan ganda dan soal essay. Semua soal terdapat pada multimedia pembelajaran interaktif. Background tampilan evaluasi berwarna ungu yang cerah sehingga siswa akan lebih tertarik untuk mengerjakan soal. Dan juga pada pilihan menu soal pilihan ganda dan essay terdapat gambar kertas, kalkulator, pensil, dan lain-lain. Dengan gambar-gambar ini diharapkan akan meningkatkan germany cognitive load. Akan tetapi tidak semua masalah dapat diselesaikan dengan baik oleh siswa. Ketika mengalami kesulitan, siswa dapat bertanya kepada teman yang lebih pintar atau kepada guru. Dengan pemberian soal evaluasi ini dapat membantu siswa untuk lebih memahami tentang materi volume kubus dan balok, sehingga dapat mengelola intrinsic cognitive load, meningkatkan germany cognitive load, dan mengurangi extraneous cognitive load.

Kegiatan selanjutnya adalah guru meminta siswa untuk saling menukarkan hasil jawabannya dan guru meminta beberapa siswa mempresentasikan hasil jawabannya. Dalam kegiatan ini, beberapa siswa mempresentasikan hasil jawabannya di depan kelas secara tertulis. Dalam kegiatan presentasi ini, antar siswa dapat saling tanya jawab dan memberikansaran. Langkah ini diperlukan agar siswa dapat menerima saran dari teman lain. Selanjutnya pada kegiatan penutup, yang pertama, guru dengan melibatkan siswa membuat kesimpulan tentang materi yang telah dipelajari. Yang kedua, guru juga melakukan refleksi dengan caramemberikan beberapa pertanyaan tentang materi yang telah dipelajari. Dan yang ketiga, guru memberikan tugas rumah.

\section{B. Deskripsi Data Hasil Angket pada Siswa Kelas 5 SDN 3 Klegen}

Angket pada penelitian ini terdiri dari 10 pertanyaan tentang pembelajaran melalui multimedia pembelajaran interaktif berbasis cognitive load theory (CLT) pada siswa kelas V SD. Data hasil angket siswa kelas 5 SDN 3 Klegen disajikan pada tabel berikut:

Tabel 2 Data Hasil Angket Siswa Kelas 5 SDN 3 Klegen 


\begin{tabular}{|c|c|c|c|c|}
\hline No. & Aspek Penilaian & TSEV & S-max & V (\%) \\
\hline 1. & $\begin{array}{l}\text { Desain atau tampilan mutimedia interaktif ini } \\
\text { menarik. }\end{array}$ & 94 & 104 & 90,38 \\
\hline 2. & $\begin{array}{l}\text { Materi pembelajaran Volume Kubus dan Balok yang } \\
\text { disajikan dengan menggunakan mutimedia interaktif } \\
\text { ini lebih menarik. }\end{array}$ & 88 & 104 & 84,61 \\
\hline 3. & $\begin{array}{l}\text { Dengan menggunakan mutimedia interaktif ini, dapat } \\
\text { memudahkan Anda dalam memahami materi } \\
\text { Volume Kubus dan Balok. }\end{array}$ & 85 & 104 & 81,73 \\
\hline 4. & $\begin{array}{l}\text { Mutimedia interaktif ini dapat menyajikan materi } \\
\text { secara urut dan menarik untuk dipahami. }\end{array}$ & 96 & 104 & 92,31 \\
\hline 5. & $\begin{array}{l}\text { Bahasa yang digunakan dalam mutimedia interaktif } \\
\text { ini dapat Anda pahami dengan mudah. }\end{array}$ & 92 & 104 & 88,46 \\
\hline 6. & $\begin{array}{l}\text { Tulisan yang digunakan dalam mutimedia interaktif } \\
\text { ini mudah untuk dibaca. }\end{array}$ & 94 & 104 & 90,38 \\
\hline 7. & $\begin{array}{l}\text { Gambar yang digunakan dalam mutimedia interaktif } \\
\text { ini menarik. }\end{array}$ & 89 & 104 & 85,58 \\
\hline 8. & $\begin{array}{l}\text { Dengan belajar menggunakan multimedia interaktif } \\
\text { ini dapat menambah wawasan pengetahuan tentang } \\
\text { materi Volume Kubus dan Balok. }\end{array}$ & 91 & 104 & 87,50 \\
\hline 9. & $\begin{array}{l}\text { Dengan belajar menggunakan multimedia interaktif } \\
\text { ini dapat meningkatkan motivasi belajar. }\end{array}$ & 92 & 104 & 88,46 \\
\hline \multirow[t]{3}{*}{10.} & $\begin{array}{l}\text { Mutimedia interaktif ini sangat berguna untuk belajar } \\
\text { memahami materi pelajaran matematika. }\end{array}$ & 97 & 104 & 93,27 \\
\hline & Jumlah & 918 & 1040 & \\
\hline & Prosentase & & & 88,27 \\
\hline
\end{tabular}

Dari tabel di atas menunjukkan bahwa:

1) Hasil rata-rata skor angket adalah $88,27 \%$, sehingga hasil angket dinyatakan baik

2) Hasil uji pada kriteria indikator yang pertama yaitu desain atau tampilan mutimedia interaktif ini menarik mendapatkan skor sebesar 90,38 \%, sehingga dinyatakan baik.

3) Hasil uji pada kriteria indikator yang kedua yaitu materi pembelajaran Volume Kubus dan Balok yang disajikan dengan menggunakan mutimedia interaktif ini lebih menarik mendapatkan skor sebesar $84,61 \%$, sehingga dinyatakan baik.

4) Hasil uji pada kriteria indikator yang ketiga yaitu dengan menggunakan mutimedia interaktif ini, dapat memudahkan Anda dalam memahami materi Volume Kubus dan Balok mendapatkan skor sebesar 81,73\%, sehingga dinyatakan baik.

5) Hasil uji pada kriteria indikator yang keempat yaitu mutimedia interaktif ini dapat menyajikan materi secara urut dan menarik untuk dipahami, mendapatkan skor sebesar $92,31 \%$, sehingga dinyatakan baik. 
6) Hasil uji pada kriteria indikator yang kelima yaitu bahasa yang digunakan dalam mutimedia interaktif ini dapat Anda pahami dengan mudah, mendapatkan skor sebesar $88,46 \%$, sehingga dinyatakan baik.

7) Hasil uji pada kriteria indikator yang keenamyaitu tulisan yang digunakan dalam mutimedia interaktif ini mudah untuk dibaca, mendapatkan skor sebesar 90,38 $\%$, sehingga dinyatakan baik.

8) Hasil uji pada kriteria indikator yang ketujuh yaitu gambar yang digunakan dalam mutimedia interaktif ini menarik, mendapatkan skor sebesar $85,58 \%$, sehingga dinyatakan baik.

9) Hasil uji pada kriteria indikator yang kedelapan yaitu dengan belajar menggunakan multimedia interaktif ini dapat menambah wawasan pengetahuan tentang materi Volume Kubus dan Balok, mendapatkan skor sebesar $87,50 \%$, sehingga dinyatakan baik.

10) Hasil uji pada kriteria indikator yang kesembilan yaitu dengan belajar menggunakan multimedia interaktif ini dapat meningkatkan motivasi belajar, mendapatkan skor sebesar $88,46 \%$, sehingga dinyatakan baik.

11) Hasil uji pada kriteria indikator yang kesepuluh yaitu Mutimedia interaktif ini sangat berguna untuk belajar memahami materi pelajaran matematika, mendapatkan skor sebesar 93,27 \%, sehingga dinyatakan baik.

Dari hasil wawancara dengan beberapa siswa didapatkan hasil bahwa siswa juga sangat menyukai pembelajaran yang dilakukan oleh guru. Dan juga multimedia pembelajaran interaktif berbasis CLT ini background-nya lebih berwarna, jadi siswa lebih menarik dan lebih tertarik untuk belajar matematika.

\section{Deskripsi Data Hasil Tes pada Siswa Kelas V SDN 3 Klegen}

Selain angket, kevalidan multimedia pembelajaran interaktif berbasis CLT juga diujikan dengan melihat hasil belajar siswa setelah menggunakan multimedia pembelajaran interaktif berbasis CLT. Hasil evaluasi terhadap multimedia pembelajaran interaktif berbasis CLT yang digunakan berupa tes pilihan ganda dan tes uraian. Standart Ketuntasan Minimal (SKM) mata pelajaran Matematika kelas 5 di SDN 3 Klegen Kota Madiun adalah 70. Berikut adalah hasil tes siswa kelas 5SDN 3 Klegen:

Tabel 3 Data Hasil Tes SDN 3 Klegen

\begin{tabular}{|c|l|c|c|}
\hline No. & \multicolumn{1}{|c|}{ Nama } & Pre-tes & Post-tes \\
\hline 1. & ACA & 60 & 85 \\
\hline 2. & AAN & 65 & 80 \\
\hline 3. & ADA & 65 & 96 \\
\hline 4. & ACR & 60 & 78 \\
\hline 5. & AUH & 75 & 100 \\
\hline 6. & ANH & 70 & 84 \\
\hline 7. & BFK & 70 & 80 \\
\hline 8. & DQSW & 60 & 75 \\
\hline 9. & DRF & 50 & 78 \\
\hline 10. & FV & 55 & 75 \\
\hline 11. & HAR & 50 & 75 \\
\hline
\end{tabular}




\begin{tabular}{|c|l|c|c|}
\hline 12. & JAF & 50 & 75 \\
\hline 13. & LINR & 65 & 80 \\
\hline 14. & LAA & 70 & 84 \\
\hline 15. & FAR & 50 & 55 \\
\hline 16. & OGS & 50 & 55 \\
\hline 17. & PARA & 75 & 96 \\
\hline 18. & RTA & 50 & 55 \\
\hline 19. & RA & 65 & 80 \\
\hline 20. & RCP & 70 & 84 \\
\hline 21. & RC & 75 & 94 \\
\hline 22. & RH & 60 & 78 \\
\hline 23. & RID & 55 & 60 \\
\hline 24. & SW & 60 & 78 \\
\hline 25. & VA & 60 & 75 \\
\hline 26. & YA & 65 & 86 \\
\hline & Jumlah & 61,54 & 78,5 \\
\hline & Rata-Rata & & \\
\hline
\end{tabular}

Dari tabel diatas dapat diketahui bahwa nilai rata-rata kelas 5 SDN 3 Klegen sebesar 78, 5 dari total siswa 26. Pada SDN 3 Klegen, nilai terendah adalah 55 dan nilai tertinggi adalah 100. Siswa yang mendapatkan nilai dibawah KKM yaitu 70 sebanyak 4 siswa. Siswa yang mendapatkan nilai lebih dari 70 sebanyak 22 siswa. Hal itu menunjukkan bahwa $84,61 \%$ siswa sudah memahami materi volume kubus dan volume balok.

\section{Kesimpulan dan Saran}

Berdasarkan hasil penelitian dan pembahasan, didapatkan bahwa setiap pertemuan pada pembelajaran dengan menggunakan multimedia pembelajaran interaktif berbasis cognitif load theory (CLT) terbagi dalam tiga kegiatan yaitu kegiatan awal, kegiatan inti, dan kegiatan penutup. Hasil rata-rata skor angket adalah 88,27 \%, sehingga hasil angket dinyatakan baik. Dan juga hasil nilai rata-rata kelas 5 SDN 3 Klegen sebesar 78,5 dari total siswa 26 . Siswa yang mendapatkan nilai dibawah KKM yaitu 70 sebanyak 4 siswa. Siswa yang mendapatkan nilai lebih dari 70 sebanyak 22 siswa. Hal itu menunjukkan bahwa $84,61 \%$ siswa sudah memahami materi volume kubus dan volume balok.

Saran yang dapat dikemukakan oleh peneliti adalah dalam membuat multimedia pembelajaran interaktif sebaiknya memperhatikan karakter siswa dan sebaiknya dalam membuat multimedia pembelajaran menggunakan software selain macromedia flash seperti berupa aplikasi HP yang didalamnya terdapat materi yang dilengkapi dengan suara, gambar animasi seperti kartun, dan video.

\section{DAFTAR PUSTAKA}

Akbar, Sa'dun. 2010. Penelitian Tindakan Kelas (Edisi Revisı). Yogyakarta: Cipta Media. 
Crawford, M., L. 2001. Teaching and Contextually, Research, Rationale, and Techniques for Improving Student Motivation and Achievement In Mathematics and Science. CORD, Leading in Change in Education.

Ghony, Djunaidi dan Almanshur, Fauzan. (2016). Metodologi Penelitian Kualitatif. Yogyakarta: Ar-Ruzz Media.

Kuan, Nigel Choon Hao. 2010. Integrating Link Maps Into Multimedia: an Investigation. Tesis tidak diterbitkan. Sydney: University of Sydney.

Orton, A.1992. Learning Mathematics: Issues, Theory, and Practice. Great Britain: Redwood Books.

Plass, J. L., dkk. 2010. Cognitive Load Theory. Cambridge: Cambridge University Press.

Putra, E. D. 2011. Pembelajaran Kooperatif Tipe Investigasi Kelompok Untuk Meningkatkan Hasil Belajar Siswa Pada Materi Kubus Dan Balok Kelas VIII SMP Negeri 2 Batu. Tesis tidak diterbitkan. Malang: Universitas Negeri Malang.

Sardiman, A. 2007. Interaksi dan Motivasi Belajar Mengajar. Jakarta: PT Raja Grafindo Persada.

Suryabrata. 2011. Metodologi Penelitian. Jakarta : Raja Grafindo Persada 